\title{
KEDUDUKAN DAN URGENSI HUKUMAN MATI TERHADAP PENANGGULANGAN PENGEDARAN NARKOTIKA DI INDONESIA DAN SEJUMLAH NEGARA DI DUNIA
}

\author{
Zainul Arifin \\ Kantor Advokat Kabupaten Situbondo \\ Email : zainularifin175@gmail.com
}

\begin{abstract}
Abstrak
Kedudukan hukuman mati terhadap pengedaran narkotika di Indonesia sebagai strategi penanggulangan terhadap pengedaran narkotika masih menimbulkan pihak yang menyetujui dan menolaknya. Pihak yang menolak hukuman mati dikenakan pada pengedar nakotika dengan alasan hak asasi manusia atau hak keberlanjutan hidup terpidana, sedangkan ada kelompok yang menyetujui pelaksanaan hukuman mati yang juga dengan alasan demi kepentingan hak asasi manusia. Pihak yang menyetujui hukuman untuk pengedar ini menilai, bahwa sanksi yang dikenakan berupa hukuman mati dapat membuat jera atau takut caloncalon pelaku yang bermaksud mengedarkan narkotika atau hak hidup banyak generasi muda ikut diselamatkan menjadi korban kecanduan narkotika akibat ketakutan di kalangan calon-calon penjahat. hukuman mati bagi pengedar narkotika dalam kajian hukum positip sudah diatur dalam Undang-Undang Nomor. 35 tahun 2009 tentang Narkotika.
\end{abstract}

Kata kunci: narkotika, hukuman, akibat, kedudukan, urgensi

\begin{abstract}
The death penalty for narcotics distribution in Indonesia as a counter strategy against narcotics distribution still raises those who approve and reject it. Parties that reject the death penalty are imposed on narcotics distributors on the grounds of human rights or the right to a life sentence, while there are groups that approve the execution of the death sentence as well as for the sake of human rights. The party who approved the sentence for the distributor ruled that sanctions imposed on the death penalty could scare or intimidate potential perpetrators who intend to distribute narcotics or livelihoods for many young people to be rescued as victims of narcotics addiction due to fear among potential criminals. the death penalty for narcotics traffickers in a positive legal study is set out in the Law of Numbers. 35 of 2009 on Narcotics.
\end{abstract}

Keywords: narcotics, punishment, consequences, position, urgency

\section{PENDAHULUAN}

Dalam Penjelasan UU Nomor 35 Tahun 2009 tentang Narkotika disebutkan Tindak pidana Narkotika tidak lagi dilakukan secara perseorangan, melainkan melibatkan banyak orang yang secara bersama - sama, bahkan merupakan satu sindikat yang terorganisasi dengan jaringan yang luas yang bekerja secara rapi dan sangat 


\section{$\mathcal{H}$ urnal Negara dan Keadilan \\ p-ISSN 2302-7010 e-ISSN 2721-9801}

rahasia baik di tingkat nasional maupun internasional. Berdasarkan hal tersebut guna peningkatan upaya pencegahan dan pemberantasan tindak pidana Narkotika perlu dilakukan pembaruan terhadap Undang-Undang Nomor 22 Tahun 1997 tentang Narkotika. Hal ini juga untuk mencegah adanya kecenderungan yang semakin meningkat baik secara kuantitatif maupun kualitatif dengan korban yang meluas, terutama di kalangan anak-anak, remaja, dan generasi muda pada umumnya. Selain itu, untuk melindungi masyarakat dari bahaya penyalahgunaan Narkotika dan mencegah serta memberantas peredaran gelap Narkotika, dalam Undang-Undang ini diatur juga mengenai Prekursor Narkotika karena Prekursor Narkotika merupakan zat atau bahan pemula atau bahan kimia yang dapat digunakan dalam pembuatan Narkotika.

Dalam Undang-Undang tersebut dilampirkan mengenai Prekursor Narkotika dengan melakukan penggolongan terhadap jenis-jenis Prekursor Narkotika. Selain itu, diatur pula mengenai sanksi pidana bagi penyalahgunaan Prekursor Narkotika untuk pembuatan Narkotika. Untuk menimbulkan efek jera terhadap pelaku penyalahgunaan dan peredaran gelap Narkotika dan Prekursor Narkotika, diatur mengenai pemberatan sanksi pidana, baik dalam bentuk pidana minimum khusus, pidana penjara 20 (dua puluh) tahun, pidana penjara seumur hidup, maupun pidana mati. Pemberatan pidana tersebut dilakukan dengan mendasarkan pada golongan, jenis, ukuran, dan jumlah Narkotika

Tidak ada negara yang tidak menginginkan kemajuan melalui pembangunan. Pembangunan terus dilakukan oleh bangsa Indonesia di tengah tantangan kejahatan yang bermacam-macam, khususnya kejahatan yang berkategori serius atau istmewa (exstra ordinary crime) seperti praktik penyalahgunaan zat-zat adiktif semacam narkotika dan obat-obat berbahaya (narkoba) dan terlarang lannya. ${ }^{1} \quad$ Kelompok penyalahguna narkoba ini dari waktu ke waktu bukananya berkurang, tapi punya kecenderungan meningkat atau bertambah meluas, khususnya jaringannya. ${ }^{2}$ Indonesia termasuk salah satu negara yang menjadi sasaran pemasaran atau pengedaran narkotika. Indonesia dianggapnya sebagai pasar strategis untuk berbisnis narkotika. ${ }^{3}$

\section{METODE PENELITIAN}

Penulis menggunakan jenis penelitian bersifat yuridis normatif, atau meneliti tentang norma-norma hukum, khususnya hukum positip (hukum yang sedang belaku di Indonesia). Penelitian ini juga bersifat deskriptif, yakni suatu penelitian deskriptif, sebagaimana ditulis oleh Soerjono Soekanto ${ }^{4}$ dimaksudkan untuk memberikan dan menggambarkan data yang seteliti mungkin tentang manusia, keadaan atau gejala-gejala lainya. Penelitian hukum dengan pendekatan yuridis normatif ini dilakukan dengan cara meneliti bahan pustaka atau data sekunder. ${ }^{5}$ Dengan pendekatan peraturan perundang-undangan, konspesional, dan komparatif (perbandingan).

${ }^{1}$ Fuad Nashir, Perkembangan Kejahatan Serius di Indonesia, LIngkar Baru, Yogyakarta, 2016, hal. 15.

${ }^{2}$ Ibid.

${ }^{3}$ Abu Hasan Zafi, Narkotika menjadi Kejahatan melebihi Terorisme, Pustaka Bangsa, Jakarta, 2016, hal. 2.

${ }^{4}$ Soerjono Soekanto, Metode Penelitian Hukum, Sinar Grafika, Jakarta, 1986, hal. 9.

${ }^{5}$ Soerjono Soekanto \& Sri Mamudji, Penelitian Hukum Normatif, Rajagrafindo Persada (Rajawali Grup), Jakarta, 2003, hal. 13-14. 


\section{Zurnal Negara dan $\mathcal{X}$ eadilan \\ p-ISSN 2302-7010 e-ISSN 2721-9801}

Penulis menggunakan teknik pengumpulan data yang relevan denganya yaitu dengan teknik dokumentasi. Dalam menganalisis data yang diperoleh, penulis menggunakan teknik analisis isi, yaitu suatu analisis terhadap isi data yang diperoleh.

\section{PEMBAHASAN}

Kita secara umum paham atau mengerti, bahwa upaya membangun manusia Indonesia tidaklah mudah. Untuk mewujudkan masyarakat Indonesia yang sejahtera, adil dan makmur yang merata materiil dan spirituil berdasarkan Pancasila dan Undang-Undang Dasar 1945, seringkali menghadapi berbagai bentuk tantangan. Meskipun demikian, upaya membangun kualitas sumber daya manusia Indonesia sebagai salah satu modal pembangunan nasional perlu ditingkatkan secara terus menerus, termasuk derajat kesehatannya di semua penduduk.

Kualitas sumberdaya manusia (SDM) selalu dalam ujian kejahatan di bidang penyalahgunaan obat-obat yang semestinya berguna untuk kesehatan. Peningkatan derajat kesehatan sumber daya manusia Indonesia dalam rangka mewujudkan kesejahteraan rakyat perlu dilakukan upaya peningkatan dibidang pengobatan dan pelayanan kesehatan, antara lain pada satu sisi dengan mengusahakan ketersediaan narkotika dan obat-obatan jenis tertentu yang sangat dibutuhkan sebagai obat-obatan untuk kesehatan, juga digunakan untuk percobaan dan penelitian yang diselenggarakan pemerintah dalam rangka kepentingan ilmu pengetahuan dan mendapat ijin dari Menteri Kesehatan.

Pada era globalisasi ini masyarakat lambat laun berkembang, dimana perkembangan itu selalu diikuti proses penyesuaian diri yang kadang-kadang proses tersebut terjadi secara tidak seimbang. Dengan kata lain, pelanggaran terhadap norma-norma tersebut semakin sering terjadi dan kejahatan semakin bertambah, baik jenis maupun polanya semakin kompleks. Perkembangan masyarakat itu disebabkan karena ilmu pengetahuan dan pola pikir serta gaya hidup masyarakat yang semakin bermacam-macam, diantaranya dengan maksud menggunakan narkoba sebagai obyek dari kebutuhan yang harus dipenuhinya, meski.untuk memenuhinya dengan cara-cara melanggar norma hukum yang berlaku.

Masyarakat berusaha mengadakan pembaharuan-pembaharuan di segala bidang. Namun kemajuan teknologi tidak selalu berdampak positif, bahkan ada kalanya berdampak negatif. Maksudnya adalah dengan kemajuan teknologi juga ada peningkatan masalah kejahatan dengan menggunakan modus operandi yang canggih.

Hal tersebut merupakan tantangan bagi aparat penegak hukum untuk mampu menciptakan penanggulangannya, khususnya dalam kasus narkotika dan obat-obatan terlarang.

Kita bisa mencermati kondisi akhir-akhir ini kejahatan narkotika dan obatobatan terlarang (narkoba) telah bersifat transnasional yang dilakukan dengan modus operandi yang tinggi dan teknologi yang canggih. Aparat penegak hukum di harapkan mampu mencegah dan menanggulangi kejahatan tersebut guna meningkatkan moralitas dan kualitas sumber daya manusia di Indonesia khususnya bagi generasi penerus bangsa. Meski demikian, kejahatan penyalahgunaan narkoba ini masih marak terjadi di masyarakat. Bahkan di 


\section{$\mathcal{H}$ urnal Negara dan Keadilan \\ p-ISSN 2302-7010 e-ISSN 2721-9801}

beberapa kelompok masyarakat, khususnya di kalangan usia muda, ada kecenderungan terjadi peningkatan atau perkembangan modus penyalahgunaannya.

Penyalahgunaan narkoba seperti di kalangan remaja atau mahasiswa, termasuk bentuk penyalahgunaan yang memprihatinkan, karena bukan hanya dari segi kuantitas, tetapi juga dari segi kualitas penyalahgunaannya yang berdampak meluas, seperti akibatnya pada diri sendiri hingga penularannya pada anggota masyarakat lain..

Di dunia ini, dapat dipahami, bahwa penyalahgunaan dan peredaran gelap narkotika, psikotropika, dan bahan berbahaya lainnya merupakan suatu kajian yang menjadi masalah dalam lingkup nasional maupun secara internasional. Pada kenyataanya, kejahatan narkotika memang telah menjadi sebuah kejahatan transnasional yang dilakukan oleh kelompok kejahatan terorganisir (organized crime). Masalah ini melibatkan sebuah sistem kompleks yang berpengaruh secara global dan akan berkaitan erat dengan Ketahanan Nasional sebuah bangsa. Baik secara langsung maupun tidak langsung, dalam perkembangannya hingga saat ini penyalahgunaan penggunaan narkoba tersebar secara luas pada berbagai jenjang usia dan berbagai lapisan masyarakat. Mulai dari jenjang usia muda hingga tua, kelas ekonomi bawah sampai dengan menengah ke atas. Namun yang patut mendapat perhatian lebih adalah adanya kecenderungan peningkatan angka yang signifikan pada lapis usia produktif.

Narkotika dan psikotropika merupakan dua bentuk zat yang berbeda bahan dan penggunaannya dalam ilmu kesehatan, kemudian untuk mempermudah penyebutannya, memudahkan orang berkomunikasi dan tidak menyebutkan istilah yang tergolong panjang, dengan demikian dapat disingkat dengan istilah "narkoba" yaitu narkotika dan obat-obatan adiktif yang berbahaya. Namun pada umumnya orang belum tahu tentang narkotika dan psikotropika karena memang dua zat tersebut dalam penyebutannya baik di media cetak maupun elektronika lebih sering diucapkan dengan istilah narkoba, meskipun mereka hanya tahu macam dan jenis dari narkoba tersebut, di antaranya ganja, kokain, heroin, pil koplo, sabu-sabu dan lain sebagainya.

Pengesahan Konvensi Wina Tahun 1971 yang mengatur kerjasama internasional dalam pengendalian, pengawasan produksi, peredaran dan penggunaan narkotika dan psikotropika serta mencegah dalam upaya pemberantasan penyalahgunaan narkotika dan psikotropika, dengan membatasi penggunaannya hanya bagi kepentingan pengobatan dan ilmu pengetahuan. Hal ini merupakan upaya pemerintah dengan penyelenggaraan kerjasama antara negara-negara lain dalam rangka suatu usaha pengawasan, peredaran dan penyalahgunaan psikotropika dan narkotika yang memberikan arahan tentang prinsip-prinsip yuridis kriminal dan aturan-aturan tentang ekstradisi.

Ditinjau dari aspek kepentingan nasional, konvensi ini dapat menjamin kepastian dan keadilan hukum dalam upaya penegakan hukum peredaran gelap narkotika dan psikotropika yang melibatkan para pelaku kejahatan lintas batas teritorial Indonesia. Di samping itu untuk kepentingan nasional, khususnya untuk kepentingan didalam negeri, akan diperoleh suatu kepastian dan kemanfaatan 


\section{Zurnal Negara dan $\mathcal{X}$ eadilan \\ p-ISSN 2302-7010 e-ISSN 2721-9801}

dalam rangka pengaturan peredaran narkotika dan psikotropika untuk kepentingan pengobatan dan ilmu pengetahuan. ${ }^{6}$

Pada dasarnya peredaran narkotika dan psikotropika di Indonesia apabila ditinjau dari aspek yuridis adalah sah keberadaannya, Undang-Undang Narkotika dan Undang-Undang Psikotropika hanya melarang terhadap penggunaan psikotropika dan narkotika tanpa izin oleh undang-undang yang dimaksud. Keadaan yang demikian ini dalam tataran empirisnya, penggunaan narkotika dan psikotropika sering disalahgunakan bukan untuk kepentingan pengobatan dan ilmu pengetahuan. Akan tetapi jauh dari pada itu, dijadikan ajang bisnis yang menjanjikan dan berkembang pesat, yang mana kegiatan ini berimbas pada rusaknya mental baik fisik maupun psikis pemakai narkoba khususnya generasi muda.

Penegakan hukum terhadap tindak pidana narkotika dan psikotropika, telah banyak dilakukan oleh aparat penegak hukum dan telah banyak mendapat putusan hakim. Dengan demikian, penegakan hukum ini diharapkan mampu menjadi faktor penangkal terhadap merebaknya perdagangan gelap serta peredaran narkotika dan psikotropika, tapi dalam kenyataannya justru semakin intensif dilakukan penegakan hukum, semakin meningkat pula peredaran serta perdagangan gelap narkotika dan psikotropika tersebut.

Penegakan hukum terhadap tindak pidana atau kejahatan narktika di Indonesia, khususnya dalam hal pemidanaan, seharusnya merujuk pada pendekatan norma hukum yang bersifat membina penjahat dengan cara melakukan pembinaan di lembaga pemasyarakatan, dengan demikian dapat memperbaiki terpidana di lembaga pemasyarakatan tersebut. Seharusnya hal ini mampu memberikan wacana kepada para hakim dalam merumuskan vonis penjatuhan pidana kepada para pelaku kejahatan agar mampu menangkap aspirasi keadilan masyarakat. Sementara itu, dalam kenyataan empiris di bidang pemidanaan secara umum masih menganut konsep hanya menghukum terpidana di lembaga pemasyarakatan, dengan demikian dapat memberikan gambaran bahwa kejahatan tersebut hanya terhenti sesaat dan akan muncul kembali dalam lingkungan kehidupan sosial masyarakat.

Diantara aparat penegak hukum yang juga mempunyai peran penting terhadap adanya kasus tindak pidana narkotika ialah "Penyidik", dalam hal ini penyidik POLRI, dimana penyidik diharapkan mampu membantu proses penyelesaian terhadap kasus pelanggaran hokum atau tindak pidana narkotika.

Dengan dikeluarkannya Undang-Undang No.35 tahun 2009 tentang Narkotika $^{7}$, maka penyidik diharapkan mampu membantu proses penyelesaian perkara terhadap seseorang atau lebih yang telah melakukan tindak pidana narkoba dewasa ini.

Efektifitas berlakunya Undang-Undang ini sangatlah tergantung pada seluruh jajaran penegak umum, dalam hal ini seluruh intansi yang terkait langsung, yakni penyidik Polri serta para penegak hukum yang lainnya.

${ }^{6}$ Siswantoro Sunarso. 2004. Penegakan Hukum Dalam Kajian sosiologis. Jakarta:

Raja Grafindo Persada. Hal. 1.

${ }^{7}$ Undang-Undang No. 35 tahun 2009 tentang Narkotika 


\section{$\mathcal{H}$ urnal Negara dan Keadilan \\ p-ISSN 2302-7010 e-ISSN 2721-9801}

Kenyataan yang bisa dibaca, bahwa tidak ada negara di dunia ini yang tidak dirambah dengan pengedaran narkotika. Bangsa-bangsa manapun menghadapi musuh atau penyakit yang sama dan menakutkan yang membuat dirinya harus ekstra keras untuk melawan atau menanggulanginya dengan mengerahkan segala kemampuan yang dimilikinya. ${ }^{8}$

Jaringan narkoba terus berkembang dan dimungkinkan akan terus mengembangkannya sesuai dengan targetnya dalam menguasai dunia. Ibarat rayap yang menggerogoti dari celah mana pun, begitulah serbuan sindikat narkoba internasional ke Indonesia.

Salah satu Lembaga atau badan negara yang berkompeten dalam penannggulangan narkotika adalah BNN. Badan Narkotika Nasional (BNN) barubaru ini misalnya mengungkapkan setidaknya ada tujuh negara raksasa narkoba menjadikan negara ini sebagai pasar favorit. Mereka ialah Kolombia, Peru, Bolivia, Meksiko, India, Nigeria, dan Afghanistan. Pasar narkoba di Tanah Air pun kian sesak dengan pasokan barang haram dari Malaysia, Iran, Pakistan, dan negara-negara Afrika. Padahal, beberapa tahun lalu, Indonesia cuma dijadikan negara transit oleh sindikat internasional. Namun, keuntungan besar yang didapat di Indonesia menjadi magnet bagi para gembong narkoba. Mereka pun lihai mencari celah untuk memasukkan barang haram itu. Para kurir narkoba akan singgah ke beberapa negara sebelum masuk ke Indonesia. ${ }^{9}$

Para pelaku kejahatan di bidang penyalahgunaan narkoba itu terus beraksi. Mereka inipun mengubah rute penerbangan dari internasional ke domestik. Pemeriksaan yang longgar di penerbangan domestik memuluskan masuknya narkoba. Sindikat narkoba juga memanfaatkan jalur laut untuk melebarkan sayap. Contohnya penemuan ratusan ribu ekstasi bernilai Rp24 miliar di Daan Mogot, Jakarta Barat, awal bulan ini. Pil setan itu dikirim dari Malaysia melalui 75 pelabuhan tikus di Kepulauan Riau. Bukan hanya lihai dalam jalur, sindikat perdagangan narkoba juga lihai dalam kamuflase. Awal Juni, BNN mengungkap penyelundupan sabu di dalam cakram mobil. Paket sabu asal India itu dimasukkan ke Indonesia melalui jasa penitipan barang. Ada pula penyelundupan sabu asal Malaysia dengan menggunakan jasa nelayan melalui perairan di Kota Tanjung Balai, Sumatra Utara. ${ }^{10}$

Kelompok atau kalangan bandar narkoba juga menjadikan keluarga polisi dan tentara sebagai pengguna. Ketika keluarga aparat sudah terjerat, mereka berharap para penegak hukum pun akan mau berkompromi. Bahkan jika polisi dan tentara tersebut masih terus berperang melawan narkotika, para bandar pun ikut menjadikan mereka sasaran pemasaran dengan diiming-imingi narkoba gratis. Akibatnya, jaringan narkotika bisa bertahan bahkan makin berkembang dan bahkan meluas.

Masyarakat saat ini benar-benar diserang oleh para bandar narkotika. Dengan gempuran narkotika yang kian luas dan mengerikan, perang pun seharusnya kian giat dilancarkan.

${ }^{8}$ A. Ikhwan Habib, Narkotika sebagai Musuh Bersama Masyarakat Beradab, LIngkar

Studi, Yogyakarta, 2016, hal. 14.

${ }^{9}$ http://metrotvnews.com/videoprogram/detail/2013/06/15/17739/121/MenghadangGempuran-Narkoba/Editorial\%20Media\%20Indonesia, akses 15 Mei 2019

${ }^{10}$ Ibid 


\section{Zurnal Negara dan $\mathcal{X}$ eadilan \\ p-ISSN 2302-7010 e-ISSN 2721-9801}

Pemeriksaan di berbagai jalur masuk, baik udara maupun laut, internasional maupun domestik, harus sama ketatnya. Berbagai instansi terkait juga harus sama-sama mengamankan pagar depan negara ini.

Mereka mengenal atau membuat wilayah yang sulit dijangkau apparat. Pelabuhan-pelabuhan tikus yang menjadi celah masuknya narkotika sudah saatnya dipantau dan diberantas. Penegakan hukum yang kuat juga tak bisa ditawar-tawar lagi. Sudah banyak kasus sangkaan terhadap bandar narkotika bisa diubah dengan uang pelicin. ${ }^{11}$

Ada banyak perekembangan di dunia jaringan narkotika. Status bandar diubah menjadi pengedar dan para pengedar disebut sebagai pemakai. Sebaliknya, pemakai kadang dianggap sebagai pelaku, bukan korban yang mesti mendapat rehabilitasi. Itulah yang membuat keluarga enggan melapor ke polisi bila ada anggota mereka kedapatan memakai narkoba karena khawatir berurusan dengan hukum.

Di sisi lain, ironisnya, ada bandar yang divonis mati dan mengendalikan bisnis narkoba dari balik jeruji justru mendapat grasi. 'Perang Bubat' melawan narkotika harus dilakukan secara komprehensif, dari hulu ke hilir, dengan melibatkan seluruh instansi terkait, juga menggalang partisipasi masyarakat, ${ }^{12}$ sehingga jaringan atau pengedaran narkotika bisa diatasi.

Sebagai bahan kritik bersama, dalam beberapa tahun lalu, Indonesia memang cuma menjadi negara transit atau "surga sementara" oleh sindikat internasional. Namun, label itu telah lama luntur dan mengubah wajah Indonesia menjadi destinasi penjualan (pasar transaksi dan produksi).

Indonesia semakin dipopulerkan sebagai sentra produksi narkoba, yang kondisi ini berkaitan dengan wajah hukum Indonesia yang lebih "menguntungkan" para pebisnis narkoba daripada mengubah Indonesia menjadi surga yang menyelamatkan dan mendamaikan keberlanjutan hidup generasi muda.

Selain itu, sudah demikian sering aparat kepolisian membongkar jaringan produksi narkotika. Mereka tidak jera-jeranya mendirikan pabrik barang laknat ini. Di berbagai daerah di Indonesia, kepolisian nyaris tidak mengalami atmosfir sepi dari membongkar pabrik narkotika.

Selain jaringan produksi narkotika itu, para pebisnis global juga mendapatkan angin segar untuk mewujudkan kesempatan melakukan pembunuhan generasi muda Indonesia. Mereka semakin pemberani memasuki dan mengacak-acak keadaban dan keberlangsungan konstruksi negeri. Belum lepas dari ingatan kita, sebagai contoh adalah yang dilakukan Polda Metro Jaya yang pernah berhasil menyita $351 \mathrm{~kg}$ sabu asal China. Dua pekan berikutnya, aparat Badan Narkotika Nasional (BNN) mengamankan 1,5 juta pil ekstasi yang juga asal China. ${ }^{13}$

Agak tiarap beberapa saat, gembong narkoba kembali menggila belakangan ini. Pada Kamis 11 Oktober, sebanyak 2,6 kg sabu mencoba diselundupkan di Bandara Internasional Lombok, namun digagalkan aparat. Beberapa hari berselang, di tempat yang sama ini, giliran $3,7 \mathrm{~kg}$ hasyis atau olahan ganja dapat

${ }^{11}$ Ibid.

12 Ibid.

${ }^{13}$ Mudhofar, Pengedar Narkoba sebagai Teroris Anak Muda, makalah, FGD-LPPN, Jakarta, 2012, hal. 2. 


\section{$\mathcal{H}$ urnal Negara dan Keadilan \\ p-ISSN 2302-7010 e-ISSN 2721-9801}

disita. Dari Bandara Ahmad Yani, Semarang, Jawa Tengah, 5 kg sabu juga hendak diselundupkan.

Memang dalam beberapa kasus, aparat berhasil membongkar jaringan produksi dan pengedaran narkoba, akan tetapi seperti teori gunung es, masih lebih banyak lagi jaringan yang tidak terbongkar akibat kelihaian para produsen dan pebisnisnya. Terbukti, data BNN menunjukkan 49,5 ton sabu, 147 juta ekstasi, 242 ton ganja, dan hampir 2 ton heroin lepas dari jerat petugas sepanjang 2011.

Berdasarkan kondisi tersebut, tidak salah jika kita menstigmatisasi Indonesia sebagai negeri darurat narkoba. Di samping jaringan produksi dan pengedaran yang kian berani, mereka sudah menghabisi 15 ribu warga setiap tahunnya, yang sebagian besar berasal dari kalangan generasi muda. Banyaknya generasi muda yang terbunuh ini logis, pasalnya mereka merupakan pasar empuk para pengedar.

Para produsen dan pebisnis narkoba yang sudah divonis dengan hukuman mati, ternyata mendapatkan grasi. Hukuman yang semula sudah memberikan vonis mati bagi perusak dan penghancur generasi muda ini, telah diubah oleh aparat penegak hukum (hakim) dengan hukuman yang bercorak memberi kesempatan hidup lebih lama, yang antara lain terhamin secara bertahap melalui upaya permintaan remisi dari momen-momen tertentu.

Kinetja aparat penegak hukum kita itu dinilai oleh banyak pihak belum beridealisme tinggi dalam membongkar atau mempengaruhi dunia produksi dan pasar distribusi narkoba, dari liberalisme (kebebasan) menuju keterbatasan, ketidaknyamanan, dan ketakutan. Mereka secara tidak langsung diberi keleluasan dan keberanian untuk terus menerus menjalankan aksinya, baik dengan jaringannya di luar penjara maupun pasar baru yang terbentuk di penjara.

Beberapa bulan lalu, hakim agung Imron Anwari menganulir vonis mati gembong narkotika Hanky Gunawan. Putusan hakim MA ini secara tidak langsung memberikan kesempatan bagi pebisnis narkoba dimanapun berada untuk menjadikan negeri ini sebagai "surga" transaksinya secara lebih leluasa.

Hakim itu barangkali berkaca pada saat masih Presiden Susilo Bambang Yudhoyono yang tidak setia pada janjinya yang dilontarkan pada 2006, yang dalam janjinya ini tidak akan memberikan grasi kepada terpidana narkoba tanpa terkecuali, namun kenyataannya pengurangan hukuman mati menjadi seumur hidup ia berikan kepada Meirika Franola pada 2011 dan Deni Satia Maharwan pada 2012.

Terlepas apapun alasan yuridis atau politis yang dikedepankan dalam pemberian "dispensasi" hukuman pada narapidana narkoba, jelas ini berdampak besar bagi keberlanjutan hidup generasi sekarang dan mendatang. Mereka ini akan kian dijadikan lahan empuk pembantaian para produsen dan pebisnis narkoba, karena para aparat penegak hukum yang seharusnya melindungi, telah memberikan izin pembunuhan untuknya. ${ }^{14}$

Akhir-akhir ini kejahatan narkotika dan obat-obatan terlarang (narkoba) telah bersifat transnasional yang dilakukan dengan modus operandi yang tinggi dan teknologi yang canggih. Aparat penegak hukum di harapkan mampu mencegah dan menanggulangi kejahatan tersebut guna meningkatkan moralitas

${ }^{14}$ Afrina Susiani, Op.Cit, hal. 3. 


\section{Zurnal Negara dan $\mathcal{X}$ eadilan \\ p-ISSN 2302-7010 e-ISSN 2721-9801}

dan kualitas sumber daya manusia di Indonesia khususnya bagi generasi penerus bangsa.

Meskipun seperti itu, kejahatan penyalahgunaan narkotika ini masih marak terjadi di masyarakat. Bahkan di beberapa kelompok masyarakat, khususnya di kalangan usia muda, ada kecenderungan terjadi peningkatan atau perkembangan modus penyalahgunaannya.

Penyalahgunaan narkoba seperti di kalangan remaja atau mahasiswa, termasuk bentuk penyalahgunaan yang memprihatinkan, karena bukan hanya dari segi kuantitas, tetapi juga dari segi kualitas penyalahgunaannya yang berdampak meluas, seperti akibatnya pada diri sendiri hingga penularannya pada anggota masyarakat lain..

Permasalahan tersebut melibatkan sebuah sistem kompleks yang berpengaruh secara global dan akan berkaitan erat dengan Ketahanan Nasional sebuah bangsa. Baik secara langsung maupun tidak langsung, dalam perkembangannya hingga saat ini penyalahgunaan penggunaan narkoba tersebar secara luas pada berbagai jenjang usia dan berbagai lapisan masyarakat. Mulai dari jenjang usia muda hingga tua, kelas ekonomi bawah sampai dengan menengah ke atas. Namun yang patut mendapat perhatian lebih adalah adanya kecenderungan peningkatan angka yang signifikan pada lapis usia produktif. ${ }^{15}$

Narkotika dan obat-obat terlarang lainnya merupakan bentuk zat yang berbeda bahan dan penggunaannya dalam ilmu kesehatan, kemudian untuk mempermudah penyebutannya, memudahkan orang berkomunikasi dan tidak menyebutkan istilah yang tergolong panjang, dengan demikian dapat disingkat dengan istilah "narkoba" yaitu narkotika dan obat-obatan adiktif yang berbahaya. Namun pada umumnya orang belum tahu tentang narkotika dan psikotropika karena memang dua zat tersebut dalam penyebutannya baik di media cetak maupun elektronika lebih sering diucapkan dengan istilah narkoba, meskipun mereka hanya tahu macam dan jenis dari narkoba tersebut, di antaranya ganja, kokain, heroin, pil koplo, sabu-sabu dan lain sebagainya.

Pengesahan Konvensi Wina Tahun 1971 yang mengatur kerjasama internasional dalam pengendalian, pengawasan produksi, peredaran dan penggunaan narkotika dan psikotropika serta mencegah dalam upaya pemberantasan penyalahgunaan narkotika dan psikotropika, dengan membatasi penggunaannya hanya bagi kepentingan pengobatan dan ilmu pengetahuan. Hal ini merupakan upaya pemerintah dengan penyelenggaraan kerjasama antara negara-negara lain dalam rangka suatu usaha pengawasan, peredaran dan penyalahgunaan psikotropika dan narkotika yang memberikan arahan tentang prinsip-prinsip yuridis kriminal dan aturan-aturan tentang ekstradisi.

Ditinjau dari aspek kepentingan nasional, konvensi ini dapat menjamin kepastian dan keadilan hukum dalam upaya penegakan hukum peredaran gelap narkotika dan psikotropika yang melibatkan para pelaku kejahatan lintas batas teritorial Indonesia. Di samping itu untuk kepentingan nasional, khususnya untuk kepentingan didalam negeri, akan diperoleh suatu kepastian dan kemanfaatan dalam rangka pengaturan peredaran narkotika dan psikotropika untuk kepentingan pengobatan dan ilmu pengetahuan. ${ }^{16}$

\footnotetext{
${ }^{15}$ http://ferli1982.wordpress.com/2011/01/04/trend-perkembangan-narkotika-diindonesia/, diakses 13 April 2019

${ }^{16}$ Siswantoro Sunarso. Op.Cit. hal. 1.
} 


\section{$\mathcal{H}$ urnal Negara dan Keadilan \\ p-ISSN 2302-7010 e-ISSN 2721-9801}

Pada dasarnya peredaran narkotika dan obat-obat terlarang lainnya di Indonesia apabila ditinjau dari aspek yuridis adalah sah keberadaannya, UndangUndang Narkotika dan Undang-Undang Psikotropika hanya melarang terhadap penggunaan psikotropika dan narkotika tanpa izin oleh undang-undang yang dimaksud. Keadaan yang demikian ini dalam tataran empirisnya, penggunaan narkotika dan psikotropika sering disalahgunakan bukan untuk kepentingan pengobatan dan ilmu pengetahuan. Akan tetapi jauh dari pada itu, dijadikan ajang bisnis yang menjanjikan dan berkembang pesat, yang mana kegiatan ini berimbas pada rusaknya mental baik fisik maupun psikis pemakai narkoba khususnya generasi muda.

Penegakan hukum terhadap tindak pidana narkotika, telah banyak dilakukan oleh aparat penegak hukum dan telah banyak mendapat putusan hakim. Dengan demikian, penegakan hukum ini diharapkan mampu menjadi faktor penangkal terhadap merebaknya perdagangan gelap serta peredaran narkotika dan psikotropika, tapi dalam kenyataannya justru semakin intensif dilakukan penegakan hukum, semakin meningkat pula peredaran serta perdagangan gelap narkotika dan psikotropika tersebut.

Kebijakan negara yang berkaitan dengan ketentuan perundang-undangan yang mengatur masalah narkotika dan psikotropika telah disusun dan diberlakukan, namun demikian kejahatan yang menyangkut narkotika dan psikotropika ini belum dapat diredakan. Dalam kasus-kasus terakhir telah banyak bandar-bandar dan pengedar narkoba tertangkap dan mendapat sanksi berat, namun pelaku yang lain seperti tidak mengacuhkan bahkan lebih cenderung untuk memperluas daerah operasinya. ${ }^{17}$

Dunia penegakan hukum terhadap kejahatan di Indonesia, khususnya dalam hal pemidanaan, seharusnya merujuk pada pendekatan norma hukum yang bersifat membina penjahat dengan cara melakukan pembinaan di lembaga pemasyarakatan, dengan demikian dapat memperbaiki terpidana di lembaga pemasyarakatan tersebut.

Para aparat penegak hukum yang juga mempunyai peran penting terhadap adanya kasus tindak pidana narkotika ialah penyidik, jaksa, hakim, dan pihakpihak lainnya diharapkan mampu membantu proses penyelesaian terhadap kasus pelanggaran tindak pidana atau kejahatan narkotika.

Negara menerbitkan hukum untuk mengatasi masalah kejahatan, diantaranya narkotika. Dengan dikeluarkannya Undang-Undang No.35 tahun 2009 tentang Narkotika, ${ }^{18}$ maka apparat penegak hokum (dari peyidik hingga hakim) diharapkan mampu membantu proses penyelesaian perkara terhadap seseorang atau lebih yang telah melakukan tindak pidana narkotika yang sedang merajalela di tengah masyarakat.

Urgensi hukuman mati bagi penanggulangan pengedaran narkotika di Indonesia dan sejumlah negara di dunia secara umum sama, bahwa hukuman mati tetap dijadikan pilihan oleh sejumlah negara seperti di Iran, Mesir, Malaysia, dan Indonsia untuk dijadikan sebagai sarana atau instrument terakhir dalam kaitannya dengan penanggulangan tindak pidana, yakni dengan matinya salah satu pengedar

${ }^{17}$ O.C. Kaligis \& Associates. 2002. Narkoba dan Peradilannya di Indonesia, Reformasi Hukum Pidana Melalui Perundangan dan Peradilan. Bandung: Alumni. Hal. 260.

${ }^{18}$ Undang-Undang No. 35 tahun 2009 tentang Narkotika 


\section{Zurnal Negara dan $\mathcal{X}$ eadilan \\ p-ISSN 2302-7010 e-ISSN 2721-9801}

narkotika, di negara yang bersangkutan dapat terjaga dari kemungkinan maraknya tindak pidana narkotika. Kalangan produsen narkotika dan pengedarnya akan bisa dicegah dari kemngkinan memperluas penyalahgunaan narkotika, khususnya di jalur pemasarannya, yang jelas-jelas menimbulkan kerugian bagi masa depan masyarakat dan bangsa sekarang maupun masa mendatang.

\section{KESIMPULAN}

Kedudukan hukuman mati terhadap pengedaran narkotika di Indonesia sebagai strategi penanggulangan terhadap pengedaran narkotika masih menimbulkan pihak yang menyetujui dan menolaknya. Pihak yang menolak hukuman mati dikenakan pada pengedar nakotika dengan alasan hak asasi manusia atau hak keberlanjutan hidup terpidana, sedangkan ada kelompok yang menyetujui pelaksanaan hukuman mati yang juga dengan alasan demi kepentingan hak asasi manusia. Pihak yang menyetujui hukuman untuk pengedar ini menilai, bahwa sanksi yang dikenakan berupa hukuman mati dapat membuat jera atau takut calon-calon pelaku yang bermaksud mengedarkan narkotika atau hak hidup banyak generasi muda ikut diselamatkan menjadi korban kecanduan narkotika akibat ketakutan di kalangan calon-calon penjahat. hukuman mati bagi pengedar narkotika dalam kajian hukum positip sudah diatur dalam Undang-Undang Nomor. 35 tahun 2009 tentang Narkotika.

Buku

\section{DAFTAR PUSTAKA}

Abu Hasan Zafi, Narkotika menjadi Kejahatan melebihi Terorisme, Pustaka Bangsa, Jakarta, 2016.

A. Ikhwan Habib, Narkotika sebagai Musuh Bersama Masyarakat Beradab, LIngkar Studi, Yogyakarta, 2016

Fuad Nashir, Perkembangan Kejahatan Serius di Indonesia, LIngkar Baru, Yogyakarta, 2016.

Mudhofar, Pengedar Narkoba sebagai Teroris Anak Muda, makalah, FGD-LPPN, Jakarta, 2012.

O.C. Kaligis \& Associates. 2002. Narkoba dan Peradilannya di Indonesia, Reformasi Hukum Pidana Melalui Perundangan dan Peradilan. Bandung: Alumni.

Soerjono Soekanto, Metode Penelitian Hukum, Sinar Grafika, Jakarta, 1986.

Soerjono Soekanto \& Sri Mamudji, Penelitian Hukum Normatif, Rajagrafindo

Persada (Rajawali Grup), Jakarta, 2003.

Siswantoro Sunarso. 2004. Penegakan Hukum Dalam Kajian sosiologis. Jakarta: Raja Grafindo Persada.

Undang-Undang No. 35 tahun 2009 tentang Narkotika

\section{Internet}

http://metrotvnews.com/videoprogram/detail/2013/06/15/17739/121/Menghadang -Gempuran-Narkoba/Editorial\%20Media\%20Indonesia, akses 15 Mei 2019

http://ferli1982.wordpress.com/2011/01/04/trend-perkembangan-narkotika-diindonesia/, diakses 13 April 2019 